\title{
KERENTANAN PESISIR TERHADAP BENCANA TANAH LONGSOR DI BUNGUS, SUMATERA BARAT DAN SEKITARNYA MENGGUNAKAN METODE STORIE
}

\author{
Wisnu Arya Gemilang, Semeidi Husrin, Ulung Jantama Wisha, dan Gunardi Kusumah \\ Loka Penelitian Sumber Daya Kerentanan Pesisir, Balitbang KP, KKP \\ JI. Raya Padang-Painan Km 16, Teluk Bungus \\ wisnu.gemilang@yahoo.co.id
}

\begin{abstract}
Abstrak. Daerah Teluk Bungus dan sekitarnya secara administratif termasuk dalam wilayah Kecamatan Bungus - Teluk Kabung terletak pada bagian Selatan Kota Padang - Sumatera Barat merupakan salah satu kawasan yang masuk dalam zona potensi terjadi gerakan tanah tinggi hingga menengah. Tulisan ini bertujuan untuk mengklasifikasikan tingkat kerentanan daerah rawan gerakan tanah daerah pesisir Teluk Bungus menggunakan metode Storie (Storie, 1978 ; Sitorus, 1995) berdasarkan karakteristik fisik berupa tataguna lahan, kelerengan, geologi dan curah hujan setempat. Klasifikasi tingkat kerentanan gerakan tanah menggunakan metode Storie di kawasan Bungus dan sekitarnya dan menghasilkan lima tingkat kerentanan gerakan tanah, yaitu sang

at rendah, rendah, sedang, tinggi dan sangat tinggi. Secara umum klasifikasi tersebut menunjukkan bahwa sebagian besar lokasi longsor memang berada pada daerah dengan tingkat kerentanan gerakan tanah sedang hingga rendah. Kerentanan gerakan tanah di daerah penelitian dipengaruhi oleh kemiringan lereng dan litologi atau jenis tanah, serta curah hujan sebagai faktor pemicu terjadinya gerakan tanah.

Kata Kunci: Kerentanan Pesisir, Longsor, Metode Storie, Teluk Bungus
\end{abstract}

ABSTRACT. Bungus Bay area and surrounding administratively is part ofBungus District -Teluk Kabung is located in the southern part of Padang - West Sumatra, that is one of regions that classified into potential zone ofmedium to high land movement occurrance. The aims of this research is to classify vulnerability level of land movement in Bungus Baycoastal area using Storie methods (Stories, 1978; Sitorus, 1995) based on the physical characteristics form of landuse planning, slope, geology and local rainfall. Vulnerability classification of ground movement is using Storie methods in Bungus and surrounding areas and itproduced five vulnerability classification of ground movement, such as very low, low, medium, high and very high. The classification generally shows that most of landslide location was located in the area with medium - low level of vulnerability. Land movement vulnerability in this study area is influenced by slope and lithology or soil type, besides the rainfall level alsoone of the main factorthat cause the land movement.

Key Words: Coastal Vulnerability, Landslide, Bungus Bay, Storie method

\section{PENDAHULUAN}

Wilayah Provinsi Sumatera Barat merupakan salah satu daerah yang paling rawan terhadap bencana gerakan tanah di Indonesia. berdasarkan pemantauan Badan Geologi, Pusat Vulkanologi dan Mitigasi Bencana Geologi, pada Agustus 2015, secara nasionalterbagi atas wilayah yang memiliki kerentanan gerakan tanah yang berpotensi menengah hingga tinggi, pada tahun 2011 tercatat terjadi 21 kali bencana gerakan tanah di Sumatera Barat yang tersebar di beberapa Kabupaten (Anonim, 2015). Hal ini terjadi antara lain disebabkan oleh faktor curah hujan yang tinggi, kemiringan lereng yang sangat terjal > 70 (100 $150 \%)$ dan merupakan daerah yang tergolong rawan gerakan tanah (zona merah). Daerah Teluk Bungus dan sekitarnya secara administratif termasuk dalam wilayah Kecamatan Bungus - Teluk Kabung terletak pada bagian Selatan Kota Padang Sumatera Barat (Gambar 1) merupakan salah satu kawasan yang masuk dalam zona potensi terjadi gerakan tanah tinggi hingga menengah (Pusat Vulkanologi dan Mitigasi Bencana Geologi, Sumbar, 2015).

Wilayah Pesisir Teluk Bungus dan Sekitarnya merupakan salah satu area pariwisata pesisir atau pantai yang banyak dikunjungi wisatawan domestic maupun wisatawan mancanegara, merujuk pada kejadian tebing longsor di Pantai Sadranan, 
Gunungkidul, Yogyakarta pada 17 Juni 2015 menewaskan empat orang wisatawan dan dua orang luka-luka (Mustaqim, 2015), sehingga perlu dilakukan beberapa upaya untuk mengurangi dampak terjadinya gerakan tanah di wilayah pesisir Teluk Bungus, diperlukan pengetahuan mendetail mengenai tingkat kerentanan wilayah pesisir Teluk Bungus. Tulisan ini bertujuan untuk mengklasifikasikan tingkat kerentanan daerah rawan gerakan tanah daerah pesisir Teluk Bungus menggunakan metode Storie (Storie, 1978 ; Sitorus, 1995) berdasarkan karakteristik fisik berupa tataguna lahan, kelerengan, geologi dan curah hujan setempat. Kerentanan gerakan tanah di pesisir Teluk Bungus diindikasikan sangat dipengaruhi oleh faktor fisik berupa: geologi, topografi, tataguna lahan dan curah hujan. Informasi klasifikasi tingkat kerentanan daerah rawan gerakan tanah di pesisir Teluk Bungus berdasarkan karakteristik fisik tersebut bermanfaat untuk keperluan tata ruang wilayah dna mitigasi bencana khususnya di wilayah pariwisata pesisir atau pantai.

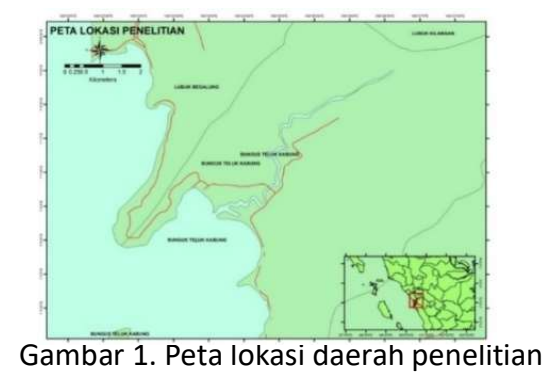

\section{METODOLOGI}

Klasifikasi tingkat kerentanan gerakan tanah dilakukan menggunakan metode Storie (Sitorus, 1995). Parameter yang digunakan dalam klasifikasi tingkat kerentanan adalah tataguna lahan, kemiringan lereng, jenis tanah dan curah hujan. Data tataguna lahan dan elevasi kontur pesisir Teluk Bungus dan Sekitarnya didapatkan dari Peta Rupa Bumi Indonesia Skala 1:25.000. Pengaruh faktor geologi didekati dari kepekaan terhadap erosi berbagai jenis tanah hasil pelapukan batuan yang menyusun daerah penelitian. Peta jenis tanah didapatkan dari Peta Jenis Tanah milik Badan Perencanaan Pembangunan Daerah Pemerintah Kota Padang 2008 - 2028 (Bappeda, Sumbar, 2007).
Data curah hujan didapatkan dari data pengamatan yang dilakukan di Statiun 96161 (Maritim Teluk Bayur) yang terletak di 100,0304' E dan 1,162' S. Data dicatat setiap harinya selama 8 tahun (2002 2009) dengan kondisi tertentu untuk setiap data setnya. Data curah hujan tersebut diolah sehingga didapatkan tipe curah hujan yang ada di wilayah pesisir Teluk Bungus dan sekitarnya. Pengolahan data masing - masing parameter dilakukan menggunakan perangkat lunak sistem infromasi geografis ArcMap 10.0, untuk selanjutnya dilakukan pengekelasan dan pembobotan. Perhitungan tingkat kerentanan terhadap gerakan tanah dilakukan dengan menggunakan metode Storie (Sitorus, 1995), kemudian dilakukan tumpeng tindih peta - peta parameter fisik untuk menghasilkan peta tingkat kerentanan gerakan tanah (Gambar 3).

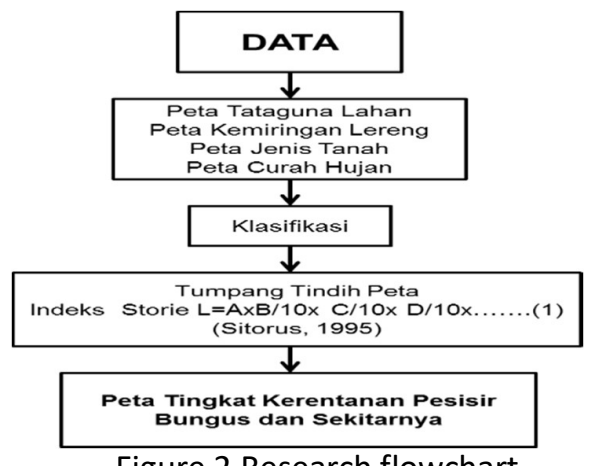

Figure 2.Research flowchart

\section{Metode Storie}

Indeks Storie merupakan metode semikuantitatif untuk penilaian (rating) tanah berdasarkan karakteristik tanah umumnya untuk menentukan potensi pemanfaatan tanah dan kapasitas produktivitas tanah (Storie 1978, Reganold dan Singer 1979). Metode ini tidak memperhitungkan faktor fisik lainnya atau faktor ekonomi yang mungkin mempengaruhi kesesuaian tanaman di suatu lokasi. Analisisnya mudah dilakukan berbagai kategori dikelompokkan menjadi beberapa kategori saja. Ada empat atau lima parameter yang lazim dievaluasi yaitu :
A : Kedalaman tanah dan tekstur;
B : Permeabilitas tanah ;
C: Sifat Kimia tanah
D: Drainase, limpasan permukaan; 
E: Iklim

Indeks dihitung dengan perkalian parameterparameter yaitu :

$$
\mathrm{S}_{\text {index }}=\mathrm{AxB} \mathrm{B} \mathrm{CxD} \mathrm{xE}
$$

Metode ini memiliki kelemahan adalah jika ada suatu kategori parameter memiliki nilai nol, maka hasil perkalian (Indeks Storie) akan menjadi nol dan tanah dianggap memiliki keterbatasan fisik dan tidak sesuai untuk keperluan lahan pertanian. Penggunaan Indeks Storie di Indonesia selain di bidang pertanian juga telah diaplikasikan untuk penentuan tingkat kerentanan gerakan tanah (Sitorus, 1995 dan Arifin, e.l, 2006) dengan modifikasi parameter pada Indeks Storie sebagai berikut :

$$
\begin{aligned}
& \mathrm{L}=\mathrm{L}=\mathrm{A} \times \mathrm{B} / 10 \times \mathrm{C} / 10 \times \mathrm{D} / 10 \times \\
& \text { Dimana : } \\
& \mathrm{L}=\text { tingkat kerentanan } \\
& \mathrm{A}=\text { tataguna lahan } \mathrm{B}=\text { kemiringan lereng } \\
& \mathrm{C}=\text { jenis tanah } \quad \mathrm{D}=\text { curah hujan }
\end{aligned}
$$

Pendekatan modifikasi Indeks Storie ini digunakan pada penentuan tingkat kerentanan gerakan tanah di Pesisir Teluk Bungus dan Sekitarnya.

\section{Tataguna Lahan}

Pengkelasan dan penentuan nilai bobot pembuatan peta tataguna lahan menggunakan tingkat erosi berdasarkan Tabel 1.

\section{Kemiringan Lereng}

Terdapat tiga tipe lereng yang rentan untuk bergerak Karnawati (2003), yaitu ;

a. Lereng yang tersusun oleh tumpukan tanah residu yang didasari oleh batuan atau tanah yang lebih kompak

b. Lereng yang tersusun oleh perlapisan batuan yang miring searah kemiringan lereng maupun berlawanan dengan kemiringan lereng

c. Lereng yang tersusun oleh blok-blok batuan.

Pengekelasan dan penentuan nilai bobot pembuatan peta kemiringan lereng menggunakan persentase kemiringan lereng (Tabel 2).

Tabel 1. Klasifikasi Pemanfaatan Lahan (Karnawati, 2003)

\begin{tabular}{|c|c|c|}
\hline Kelas tataguna Lahan & Tingat Erosi & Bobot \\
\hline Hutan tidak sejenis & Tidak peka terhadap erosi & 1 \\
\hline Hutan sejenis & Kurang peka terhadap erosi & 2 \\
\hline Perkebunan & Agak peka terhadap erosi & 3 \\
\hline Pemukiman, Sawah, Kolam & Peka terhadap erosi & 4 \\
\hline Tegalan, Tanah terbuka & Sangat peka terhadap erosi & 5 \\
\hline
\end{tabular}

Tabel 2. Klasifikasi Kemiringan Lereng berdasarkan Van

\begin{tabular}{|c|c|c|c|}
\multicolumn{4}{|c|}{ Zuidam, 1983} \\
\hline Kemiringan (\%) & Kelas lereng & Satuan morfologi & Bobot \\
\hline $0-8$ & Datar & Dataran & 1 \\
\hline$>8-15$ & Landai & Perbukitan berelief halus & 2 \\
\hline$>15-25$ & Agak Curam & Perbukitan berelief sedang & 3 \\
\hline$>25-45$ & Curam & Perbukitan berelief kasar & 4 \\
\hline$>45$ & Sangat Curam & Perbukitan berelief sangat kasar & 5 \\
\hline
\end{tabular}

\section{Metode Storie}

Storie indeks adalah metode semikuantitatif untuk scoring tanah berdasarkan karakteristik tanah untuk menentukan kapasitas pemanfaatan tanah dan tanah produktivitas potensial (Kisah 1978, Reganold dan Singer 1979). Faktor lain fisik atau faktor-faktor ekonomi, yang mungkin mempengaruhi kesesuaian perkebunan, tidak memperhitungkan. Ada empat sampai lima parameter yang biasanya dievaluasi:
A. Soil Depth and Texture
B. Soil Permeabilty
C. Soil Chemical Characteristic
D. Drainage, runoff
E. Climate

Storie indeks dapat dihitung berdasarkan :

$\mathrm{S}_{\text {index }}=\mathrm{AxBxCxDxE}$

Kelemahan metode ini akan muncul ketika hanya satu parameter memiliki nilai nol, yang membuat rumus Storie Indeks menghasilkan nol produk, yang menunjukkan tanah keterbatasan fisik, yang tidak cocok untuk pertanian.

\section{Jenis tanah}

Pengkelasan dan penentuan nilai bobot jenis tanah menggunakan tingkat kepekaan erosi jenis tanah terhadap kerentanan gerakan tanah (Tabel 3).

\section{Curah hujan}

Pembuatan peta curah hujan dilakukan dengan ploting data curah hujan dan di interpolasi sebaran data curah hujan tersebut sehingga diperoleh peta curah hujan. Dalam pengkelasan dan penentuan 
nilai bobot pembuatan peta curah hujan menggunakan asumsi hujan minimum hingga maksimum terhadap kerentanan gerakan tanah (Tabel 4).

\section{Klasifikasi kerentanan gerakan tanah}

Penentuan tingkat kerentanan gerakan tanah menggunakan Indeks Storie yaitu perkalian beberapa parameter yang mempunyai bobot terendah hingga tertinggi. Tingkat kerentanan tanah diasumsikan berdasarkan perkalian tersebut dari nilai bobot maksimum hingga minimum sehingga didapatkan 5 tingkat kerentanan (Tabel 5).

Tabel 3. Klasifikasi kepekaan jenis tanah terhadap tingkat erosi (Sobirin, 2013)

\begin{tabular}{llc}
\hline Jenis tanah & $\begin{array}{l}\text { Tingkat } \\
\text { erosi }\end{array}$ & Bobot \\
\hline Alluvial, Glei & $\begin{array}{l}\text { Tidak peka } \\
\text { Sedikit } \\
\text { peka }\end{array}$ & 1 \\
$\begin{array}{l}\text { Brown Forest, } \\
\text { Mediteran }\end{array}$ & Agak peka & 3 \\
$\begin{array}{l}\text { Andosol, } \\
\text { Grumosol, }\end{array}$ & Peka & 4 \\
$\begin{array}{l}\text { Podsol } \\
\text { Regosol, } \\
\text { Litosol, Orgosol }\end{array}$ & $\begin{array}{l}\text { Sangat } \\
\text { peka }\end{array}$ & 5 \\
\hline
\end{tabular}

Tabel 4. Klasifikasi intensitas curah hujan (Puslit Tanah, 2004)

\begin{tabular}{lcc}
\hline $\begin{array}{c}\text { Intensitas } \\
\text { curah hujan }\end{array}$ & Parameter & Bobot \\
\hline$<2.000$ & Kering & 1 \\
$2.000-2.500$ & Sedang/lembab & 2 \\
$2.500-3.000$ & Basah & 3 \\
$>3.000$ & Sangat basah & 4 \\
\hline
\end{tabular}

Tabel 5. Klasifikasi Tingkat Kerentanan terhadap

\begin{tabular}{|c|c|c|c|c|c|c|}
\multicolumn{8}{c|}{ Gerakan Tanah } \\
$\begin{array}{c}\text { Tatag } \\
\text { una } \\
\text { Lahan }\end{array}$ & $\begin{array}{c}\text { iring } \\
\text { an } \\
\text { lere } \\
\text { ng }\end{array}$ & $\begin{array}{c}\text { Jenis } \\
\text { Tanah }\end{array}$ & $\begin{array}{c}\text { Curah } \\
\text { hujan }\end{array}$ & & & \\
bobot & $\begin{array}{c}\text { Nilai kelas } \\
\text { bobot }\end{array}$ & $\begin{array}{c}\text { Tingkat } \\
\text { kerentanan }\end{array}$ \\
\hline 1 & 1 & 1 & 1 & 0.001 & $<0.001$ & Sangat rendah \\
\hline 2 & 2 & 2 & 2 & 0.016 & $0.001-0.016$ & Rendah \\
\hline 3 & 3 & 3 & 3 & 0.081 & $0.016-0.081$ & Sedang \\
\hline 4 & 4 & 4 & 4 & 0.256 & $0.081-0.256$ & Tinggi \\
\hline 5 & 5 & 5 & 5 & 0.625 & $>0.256$ & Sangat tinggi \\
\hline
\end{tabular}

HASIL PENELITIAN DAN DISKUSI Kondisi Geologi Daerah Penelitian

Berdasarkan Peta Geologi Lembar Painan dan bagian timurlaut Muara Siberut, Sumatera, skala 1:250.000 (Puslitbang Geologi, Bandung,1996), (Gambar 2. Peta Geologi Daerah Penelitian). Batuan dasar daerah bencana dan sekitarnya merupakan bagian dari batuan gunungapi Oligo-Miosen yang terdiri dari lava, breksi, breksi tuf, tuf hablur, ignimbrite dan tufsela, kebanyakan bersusun andesitan dan dasit berumur Miosen Awal. Lava daerah penelitian bersusun andesit berwarna abuabu gelap, porfiritik ; terdiri dari plagioklas, kuarsa dan feldspar. Breksi Vulkanik bersisipan dengan lava, tersusun atas fragmen berukuran kerikil hingga bongkah bersifat andesit, sedangkan matrik gelas vulkanik., sedangkan breksi tuf berwarna abu-abu kecokelatan fragmen (andesit dan tuf), ukuran fragmen kerikil hingga bongkah, matrik tuf, porositas sedang, kemas terbuka, sortasi buruk.

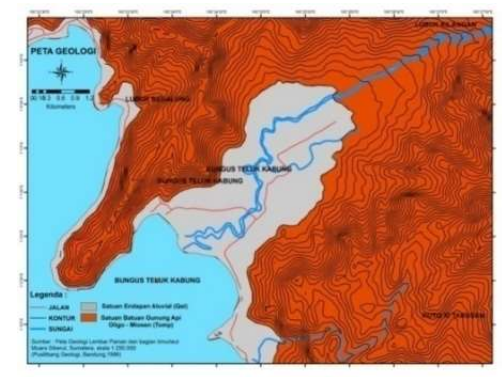

Gambar 2. Peta geologi daerah pesisir teluk Bungus dan sekitarnya (Puslitbang Geologi, Bandung,1996)

Sebagian feldspar dan tuf menjadi lempung Tanah pelapukan dilokasi penelitian didominasi oleh hasil pelapukan dari litologi breksi tuf berupa lempung pasiran berwarna cokelat, permeabilitas tinggi dan masih memperlihatkan fragmenfragmennya boulder-boulder berukuran kecil hingga besar sebagai hasil pelapukan (Foto 1.). Berdasarkan hasil pengamatan dilapangan daerah terjadinya longsor didominasi oleh litologi yang tersusun atas pelapukan batuan breksi tuf, yang mengandung fragmen berukuran boulder karena matrik telah mengalami proses pelapukan sehingga fragmen tersebut terlihat seperti bagian material lepas dan memicu terjadinya longsor akibat ketidakstabilan tersebut berukuran boulder karena 
matrik telah mengalami proses pelapukan sehingga fragmen tersebut terlihat seperti bagian material lepas dan memicu terjadinya longsor. akibat ketidakstabilan tersebut. dan memicu terjadinya longsor akibat ketidakstabilan tersebut.

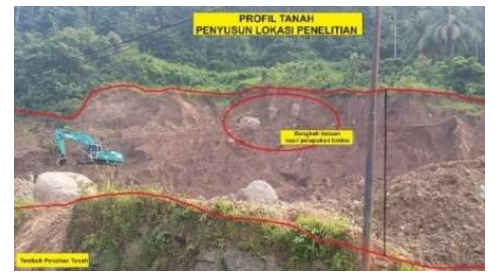

Foto 1. Hasil pelapukan batuan breksi vulkanik sebagai material penyusun tanah daerah penelitian

\section{Kondisi Tataguna lahan daerah penelitian}

Tata guna lahan di daerah penelitian secara umum (Gambar 3) dipergunakan oleh masyarakat sebagai lahan perladangan, perkebunan dan pesawahan.

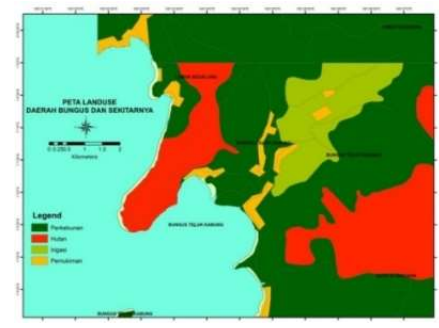

Gambar 3. Peta tataguna lahan daerah pesisir teluk Bungus dan sekitarnya

Lokasi perladangan dan perkebunan banyak dilakukan warga di bagian lereng-lereng perbukitan yang awalnya berupa hutan lindung dan hutan resapan air, kemudian dialih fungsikan sebagai lahan perladangan dan perkebunan,sedangkan lahan persawahan banyak digunakan oleh masyarakat pada daerah datar dengan morfologi dataran alluvial yang terletak dibawah perbukitan, persentase luasan tata guna lahan untuk persawahan lebih luas dibandingkan dengan area tata guna lahan sebagai perkebunan dan perladangan. Bukan hanya sebagai area perladangan dan perkebunan, yang dilakukan di lereng-lereng perbukitan namun sebagian masyarakat Bungus dan sekitarnya mendirikan rumah-rumah hunian di bagian lereng yang cukup curam, sehingga dengan kondisi tersebut mengganggu kestabilan lereng-lereng, terutama batuan penyusun lereng tersebut yang berakibat terjadinya pergerakan masa batuan dari lereng ke bawah lereng/ longsor (Foto 3.)

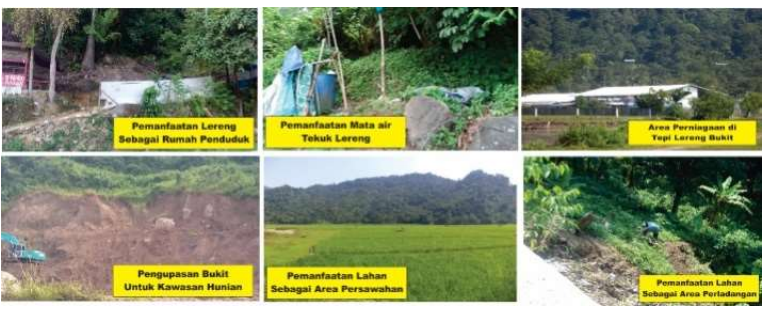

Foto 3. Tataguna lahan daerah penelitian

\section{Kemiringan lereng}

Analisis kemiringan lereng berdasarkan pengolahan data menggunakan software ArcScene 9.3 bahwa daerah pesisir teluk Bungus dan sekitarnya morfologi perbukitan dengan kemiringan lereng yang cukup bervariasi dan luasan yang berbeda-beda, dengan luasan masing - masing kemiringan lereng(Gambar 4) yaitu datar ( 27,3 ), landai ( 20,46), agak curam ( $18,38 \%)$, curam ( 29,45\%) dan sangat terjal (4.41\%). Daerah penelitian didominasi oleh jenis kemiringan datar landai. Umumnya bentukan lahan dengan kemiringan lereng datar - landau merupakan area persawahan dan wilayah dataran alluvial yang terbentuk akibat proses transportasi dan sedimentasi sungai, dan juga merupakan wilayah pasang-surut air laut.

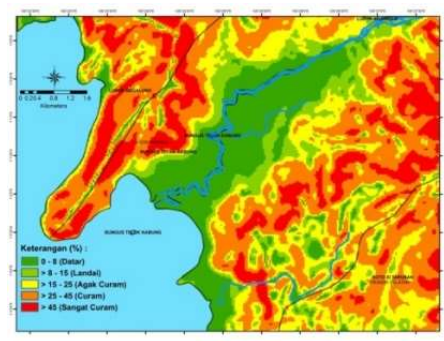

Gambar 4. Peta kemiringan lereng daerah pesisir Bungus dan sekitarnya

\section{Jenis tanah}

Peta jenis tanah berdasarkan Peta Jenis Tanah milik Badan Perencanaan Pembangunan Daerah Pemerintah Kota Padang 2008 - 2028 (Gambar 5), menunjukkan bahwa daerah pesisir Bungus dan sekitarnya tersusun oleh beberapa jenis tanah yaitu Aluvial (32.45\%), Andosol (21,36\%) dan Komplek 
Podsolik Merah Kuning Latosol dan Litosol (46.19\%). Berdasarkan pembagian luasan jenis tanah yang ada pada wilayah pesisir teluk Bungus dan sekitarnya didominasi oleh Komplek Podsolik Merah Kuning Latosol dan Litosol.

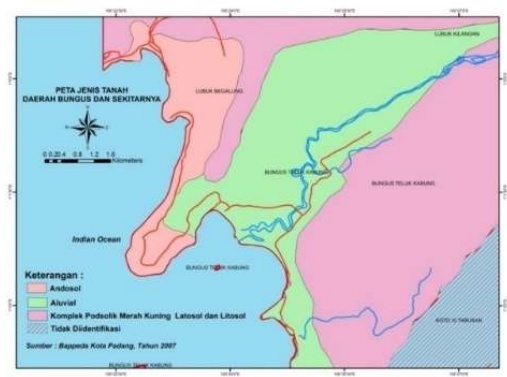

Gambar 5. Peta jenis tanah daerah Bungus dan Sekitarnya Curah Hujan

Kondisi klimatologi sangat penting untuk diketahui, karena kondisi klimatologi ini mempunyai pengaruh terhadap proses geomorfologi suatu daerah, baik intensitas ataupun tipe proses yang terjadi, termasuk didalamnya proses longsor, kondiri hidrologi maupun pembentukan lahan. Ratarata curah hujan tahunan yang turun didaerah penelitian berdasarkan data pengamatan yang dilakukan di Statiun 96161 (Maritim Teluk Bayur) yang terletak di 100,0304' E dan 1,162' S. Berdasarkan variasi tempat, wilayah Bungus dan sebagian wilayah Kabupaten Pesisir Selatan merupakan daerah dengan tipe hujan $B$, pola hujan bulannya memiliki dua puncak. Curah hujan di kawasan Bungus sepanjang tahun didominasi oleh bulan-bulan basah, dengan nilai curah hujan ratarata $>200 \mathrm{~mm}$. Perbedaan antara bulan basah dan bulan kering hampir dikatakan tidak ada. Curah hujan tertinggi berada pada bulan Oktober dan Desember hingga mencapai $579-591 \mathrm{~mm}$.

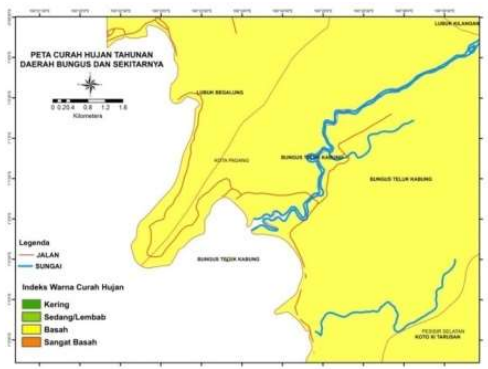

Gambar 6. Peta curah hujan tahunan daerah Bungus dan sekitarnya

\section{Hasil pengklasifikasian tingkat kerentanan}

Berdasarkan analisis hasil penelitian didapatkan daerah-daerah dengan tingkat kerentanan rendah hingga sangat tinggi (Gambar 7) sebagai berikut :

a. Daerah dengan tingkat kerentanan gerakan tanah sangat tinggi luasanya mencapai $13,28 \%$ terdapat pada sebagian Kecamatan Lubuk Begalung dan Teluk Bungus. Tataguna lahan berupa kawasan hutan, perkebunan dan sedikit kawasan pemukiman warga yang berada disekitar perbukitan. Kemiringan lereng yang mendominasi tingkat kerentanan ini masuk dalam klasifikasi kemiringan lereng sangat curam - curam. Jenis tanah penyusun didominasi oleh Andosol dan komplek podsolik merah kuning latosol dan litosol, tanah penyusun kawasan ini merupakan hasil pelapukan batuan gunungapi yaitu breksi vulkanik yang telah mengalami pelapukan dan antara fragmen dan matrik sudah tidak kompak, sehingga banyak bongkah-bongkah fragmen batuan yang tertanam di lapisan tanah yang membentuk perbukitan. Sehingga dengan kemiringan lereng yang curam - sangat curam diiringi dengan curah hujan yang basah sangat memicu terjadinya pergerakan tanah di kawasan ini.

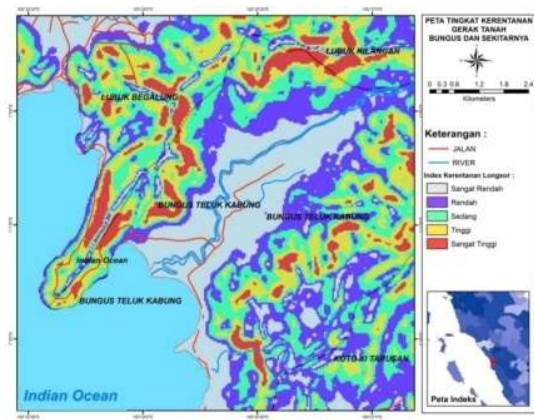

Gambar 7.Peta tingkat kerentanan gerakan tanah daerah Teluk Bungus dan Sekitarnya

b. Kawasan dengan tingkat kerentanan gerakan tanah tinggi mencakup luasan sekitar $14,35 \%$ dari keseluruhan wilayah penelitian. Daerah ini masih masuk dalam wilayah Teluk Bungus dan sebagian kecil 
berada di Kecamatan Lubuk Begalung yang berbatasan langsung dengan wilayah Teluk Bungus. Tataguna lahan yang mendominasi kawasan yaitu perkebunan yang dibuka oleh warga di bagian-bagian perbukitan dan tataguna lahan hutan, selain itu juga didirikan kawasan pemukiman di area berbukitan yang masuk zonasi tingkat kerentanan tinggi. Kemiringan lereng pada zona kerentanan tinggi didominasi oleh kemiringan lereng curam hingga agak curam. Jenis tanah penyusun kawasan ini yaitu komplek podsolik merah kuning latosol dan litosol, namun sebagian wilayah juga tersusun atas jenis tanah andosol.

c. Zonasi tingkat kerentanan sedang hampir mendominasi daerah penelitian yaitu wilayah Teluk Bungus dan sekitarnya hingga mencapai seluas $37,43 \%$. Tataguna lahan yang masuk dalam zonasi ini merupakan kawasan perkebunan, hutan dan sebagain kawasan pemukiman penduduk yang berada di sekitar wilayah perbukitan, tataguna lahan yang mendominasi zonasi ini yaitu perkebunan. Jenis tanah penyusun kawasan kerentanan sedang yaitu komplek podsolik merah kuning latosol dan litosol, dan sebagain kecil tersusun atas jenis tanah andosol. Kemiringan lereng pada kawasan ini masuk dalam kategori kemiringan lereng curam hingga landai namun secara umum didominasi oleh kemiringan lereng agak curam. Kawasan ini berbeda dengan zonasi kerentanan sangat tinggi dan tinggi, karena litologi penyusunnya tidak didominasi oleh material pelapukan batuan breksi vulkanik, namun masih memperlihatkan bongkah batuan dan litologi batuan vulkanik yang masih massif pada bagian bawah perbukitan.

d. Kawasan kerentanan gerakan tanah rendah dan sangat rendah merupakan bagian terbesar kedua luasan setelah zonasi kerentanan sedang yaitu mencapai 35,03\%. Tataguna lahan pada daerah ini terdiri dari perkebunan, pemukiman, namun secara dominan tataguna lahan kawasan ini merupakan daerah irigasi atau aliran sungai yang merupakan bagian dari dataran yang tersusun atas material endapan alluvial yang berasal dari endapan pantai maupun endapan sungai yang berasal dari daerah perbukitan. Kemiringan lereng pada daerah ini didominasi oleh kemiringan lereng landai - datar. Jenis tanah penyusun kawasan ini merupakan alluvial. Bagian daerah ini juga banyak didominasi oleh kawasan wisata pantai dan wilayah - wilayah perniagaan yang berada disekitar jalan utama lintas Padang - Painan.

Kawasan Teluk Bungus dan Sekitarnya merupakan kawasan yang sangat penting di wilayah Sumatera Barat berdasarkan hasil penentuan tingkat kerentanan gerakan tanah dengan metode Storie sehingga dapat mengidentifikasikan zonasi tingkat kerentanan gerakan tanah. Kondisi curah hujan diwilayah Bungus dan Sekitarnya masuk dalam kategori curah hujan basah, selain itu curah hujan di wilayah Padang juga cukup ekstrim dimana perubahan siklus hujan dengan cuaca kering atau panas sangat terlihat jelas sehingga dengan perubahan itu menyebabkan proses pelapukan batuan semakin meningkat. Perubahan ini juga menyebabkan berkurangnya kuat geser tanah dan menyebabkan longsoran rayapan (creeping) atau bersifat lambat. Selain tipe longsoran rayapan wilayah Bungus dan Sekitarnya juga didominasi oleh tipe gerakan tanah runtuhan, karena litologi penyusun berupa material vulkanik yang didominasi oleh breksi vulkanik yang telah mengalami pelapukan sehingga fragmen batuan yang menggantung pada bagian perbukitan dengan kemiringan lereng curam hingga sangat curam dapat memicu perpindahan masa batuan dari ketinggian tertentu ke bagian bawah perbukitan. Dibutuhkan analsisi geologi teknik terkait bangunan penahan gerakan longsor dan terutama melakukan penertiban terkait tataguna lahan yang ada di kawasan yang masuk dalam zonasi kerentanan sangat tinggi - sedang. 


\section{KESIMPULAN}

Klasifikasi tingkat kerentanan gerakan tanah menggunakan metode Storie di kawasan Bungus dan Sekitarnya menghasilkan lima tingkat kerentanan gerakan tanah, yaitu sangat rendah, rendah, sedang, tinggi dan sangat tinggi. Secara umum klasifikasi tersebut menunjukkan bahwa sebagian besar lokasi longsor memang berada pada daerah dengan tingkat kerentanan gerakan tanah sedang hingga rendah. Lokasi longsor yang berada pada daerah dengan tingkat kerentanan sangat tinggi terdapat di bagian perbukitan dengan kemiringan lereng curam hingga sangat curam di wilayah Bungus dan Lubuk Begalung.Kerentanan gerakan tanah di daerah penelitian dipengaruhi oleh kemiringan lereng dan litologi atau jenis tanah, serta curah hujan sebagai faktor pemicu terjadinya gerakan tanah. Gerakan tanah terjadi juga pada daerah dengan tataguna lahan perkebunan di kawasan perbukitan dan hutan, lereng curam sangat curam dan pada jenis tanah komplek podsolik merah kuning latosol, litosol dan andosol dengan tingkat erosi peka hingga sangat peka serta curah hujan yang masuk dalam kategori basah. Pengetahuan tingkat kerentanan gerakan tanah ini dapat bermanfaat sebagai masukan pada rencana tata ruang daerah dan upaya mitigasi gerakan tanah.

\section{DAFTAR PUSTAKA}

Sugianti Khori. dkk, 2014, Pengklasan Tingkat Kerentanan Gerakan Tanah Daerah Sumedang Selatan Menggunakan Metode Storie, Bandung, Jurnal Riset Geologi dan Pertambangan

Karnawati, D., 2003. Bencana Alam Gerakan Massa Tanah di Indonesia dan Upaya Penanggulangannya, Jurusan Teknik Geologi, Universitas Gajah Mada, Yogyakarta

O'Green, A. T., and S.B. Southard, 2005. A Revised Storie Index Model in NASIS. Soil Survey Horizons 46 (3), 98-109

Rosidi.H.M.D, 1996, Peta Geologi Lembar Painan dan Bagian Timurlaut Lembar Muara Siberut, Sumatera, Bandung, PUSTILBANG Geologi
Badan Perencanaan Pembangunan Daerah, 2007, Peta Jenis Tanah Kota Padang, Padang, Bapeda Kota Padang

Puslit Tanah, 2004. Klasifikasi Intensitas Curah Hujan. Puslit Tanah, Bogor

Mubekti, Alhasanah F., 2008. Mitigasi Daerah Rawan Tanah Longsor Menggunakan Teknik Pemodelan Sistem Infromasi Geografis. Jurnal Teknik Lingkungan, 9 (2), 121-129

Kementerian Energi dan Sumberdaya Mineral Badan Geologi, Pusat Vulkanologi dan Mitigasi Bencana Geologi, Peta Perkiraan Wilayah Potensi Terjadi Gerakan Tanah Pada Bulan Agustus 2015, Provinsi Sumbar, Pusdalops PB

Mustaqim Ahmad, 2015, Tebing Pantai Sadranaran Longsor 3 Orang Meninggal, http://jateng.metrotvnews.com/read/2015/06/17/40549 0/tebing-pantai-sadranan-longsor-tiga-orang-meninggal diakses tanggal 12 Oktober 2015

Sobarin, S., 2013. Pengolahan Sumber Daya Air Berbasis Masyarakat. Presentasi disampaikan pada Seminar Reboan Pusat Penelitian Geoteknologi LIPI, Tanggal 8 Mei 2012, Bandung

Sitorus, S., 1995. Evaluasi Sumber Daya Lahan. Tarsito, Bandung.

Storie, R., 1978. Storie Index Soil Rating. Oakland University of California Division of Agricultural Sciences Special Publication 3203

Van Zuidam, R.A., 1983. Guide to Geomorphological Aeral Photographic Interpretation 